\title{
Risk factors for multidrug-resistant $A$. baumannii and $P$. aeruginosa infection in burn care unit
}

\section{Yanık ünitesinde çoklu illaç dirençlï A. baumannii ve P. aeruginosa enfeksiyonlarında risk faktörleri}

\author{
Aynur Atillat ${ }^{1}$, S. Surrı Killıç
}

${ }^{1}$ Department of Infectious Diseases and Clinical Microbiology, School of Medicine, Ondokuzmayis University, Samsun, Turkey

${ }^{2}$ Department of Infectious Diseases and Clinical Microbiology, Samsun Training and Research Hospital, Samsun, Turkey

Corresponding author: Aynur Atilla, Department of Infectious Diseases and Clinical Microbiology, School of Medicine, Ondokuzmayis University,

Samsun, Turkey

E-mail: aynur.atilla@gmail.com

Received/Accepted: January 15,2019 / March 18, 2019

Conflict of interest: There is not a conflict of interest.

\section{SUMMARY}

Infection is a major cause of morbidity and mortality in burns patients. In spite of considerable advances in the treatment of burns, infection continues to pose the greatest danger to burn patients. We aimed to evaluate and present risk factors for multidrug resistant (MDR) Pseudomonas aeruginosa and Acinetobacter baumannii infections which are considered as a challenge to burns.From January 2009 to May 2011, a total of 465 patients hospitalized in Burn Care Unit were retrospectively reviewed including bacteria isolated and antibiotic susceptibility tests. The mean age of patients was $18.6 \pm 22.0 \mathrm{yr}$ (median=6,1-87 yr). Use of invasive device, lenght of stay in hospital, Intensive care unit lenght of stay and percentage of Total Body Surface Area were statistically significant for MDR A. baumannii and $P$. aeruginosa. In logistic regression, length of stay and the invasive device usage were found as risk factors for MDR $A$. baumannii and $P$. aeruginosa. Strict rules to control infections, lower hospitalization period and reducing the invasive device usage are essential to keep MDR and Nosocomial infections (NIs) rates lowered or at least in a stable phase.

Keywords: Burn, Infection, Multidrug Resistant

\section{ÖZET}

Yanık hastalarında enfeksiyon majör bir morbidite ve mortalite sebebidir. Yanıklardaki tedavideki belirgin ilerlemelere rağmen enfeksiyon, yanık hastalarına hala daha en büyük tehlike olmaya devam etmektedir. Yanıklardaki en büyük zorluk olarak kabul edilen, çoklu ilaç dirençli (MDR) Pseudomonas aeruginosa ve Acinetobacter baumannii enfeksiyonlarının risk faktörlerini değerlendirmeyi ve sunmayı amaçladık. Ocak 2009'dan Mayıs 2011'e kadar Yanık Tedavi Ünitesinde yatan toplam 465 hasta, izole edilen bakteriler ve antibiyotik duyarlılik testlerini de içerecek şekilde retrospektif olarak değerlendirildi. Hastaların ortalama yaşı $18.6 \pm 22.0 \mathrm{yr}$ (median=6,1-87 yıl) idi. İnvaziv cihaz kullanımı, hastanede kalış süresi, yoğun bakım ünitesinde kalış süresi ve yanık yüzey alanı yüzdesi, MDR A. baumannii and $P$. aeruginosa için istatistiksel olarak anlamlı bulundu. Lojistik regresyon analizine göre hastanede kalış süresi ve invaziv cihaz kullanımı MDR A. baumannii and $P$. aeruginosa enfeksiyonları için risk faktörü olarak bulundu. Enfeksiyon kontrolünde katı kurallar, hastanede kalış sürelerinin azaltılması ve invaziv cihaz kullanımının düşürülmesi MDR ve hastane enfeksiyonu oranlarının azaltılması veya en azından sabit tutulması yönünden elzemdir. Anahtar sözcükler: Yanık, Enfeksiyon, Çoklu ilaç direnci 


\section{INTRODUCTION}

Patients with severe burns are at higher risk for local and systemic infections. In recent years, more resistant pathogens emerged that led burn care providers to search for alternative forms of treatment. Gram-negative organisms continue to be the leading causative agents in burn patients ${ }^{1}$. Infections caused by multidrug-resistant (MDR) pathogens are associated with significant morbidity and mortality in patients with burn injuries ${ }^{2}$. Due to increased rate of worldwide resistance and infections, Pseudomonas aeruginosa, Acinetobacter isolates represent a challenge in the treatment of burns. We aimed to evaluate and present risk factors for multidrug resistant $P$. aeruginosa and A. baumannii infections in burns, as the morbidity and mortality rates with these microorganisms are considerably high.

\section{MATERIAL AND METHODS}

The electronic medical records database of burn unit and the file records of Infection Control Committee were searched to identify all patients hospitalized from January 2009 through May 2011. Nosocomial infections (NIs) were recorded according to Center for Disease Control definitions ${ }^{3}$. Total Body Surface Area (TBSA) percentage was estimated by using the Wallace's "rule of nines" method ${ }^{4}$ and a more accurate assessment was performed especially in children using the Lund and Browder chart ${ }^{5}$.

For each admission, the following information was extracted: age, sex, type of injury, \% TBSA, comorbidities (including diabetes mellitus, epilepsy, mental retardation, chronic renal failure, hypertension, cerebro vascular accident ), length of stay in hospital, length of stay in the intensive care unit (ICU), NI, causative pathogens, antimicrobial resistance, antibiotics used, devices used (ventilator, central line, and urinary catheter).

The bacteriological isolation and antibiotic susceptibility tests were evaluated using micro Scan auto 4 (Siemens). Clinical and Laboratory Standards Institute criteria were used for the antibiotic susceptibility tests ${ }^{6}$. MDR bacteria were defined as isolates resistant to at least three drugs in the following classes: $\beta$-lactams, carbapenems, aminoglycosides, and fluoroquinolones. Extensively drug-resistant (XDR) was defined as non-susceptibility to at least one agent in all but two or fewer antimicrobial categories (i.e. bacterial isolates remain susceptible to only one or two categories). XDR A. baumannii has been defined as resistance to all antimicrobial agents except polymyxins and tigecycline in this study. Pandrug-resistant (PDR) was defined as non-susceptibility to all agents in all antimicrobial categories (i.e. no agents tested as susceptible for that organism) ?. Statistical analysis: Data were analyzed using SPSS 17.0 program and given as numerical (\%) and median (min-max). Logistic regression analysis was used to predict risk and chi-square test was used in comparison of catherogical variables. Mann-Whitney $U$ test was used to compare both groups with data that not represent normal distribution. A $\mathrm{p}$ value of $<0.05$ was considered as statistically significant.

\section{RESULTS}

The records of a total of 465 patients were available. The mean age of patients was 18.6 \pm 22.0 yr (median=6,1-87 yr). $292(63 \%)$ were female and $173(37 \%)$ were male. The mean $\%$ TBSA was $18.0 \% \pm 14.0$ (range $0-95$ ). Of patients, $188(43.5 \%)$ had scald injury, 116 (26.9\%) had flame injury, 40 (9.3\%) had electrical injury, $27(6.4 \%)$ had contact injury, and 60 (13.9\%) had liquids injury (hot fluids, boiling jam). Hospitalization period was mean $18.4 \pm 17.4$ days (median $=14,2-144)$. Sixty $(60 / 465=12.9 \%)$ patients had 68 NIs with an incidence density of 9.9 infections/ 1000 patient days. Burn wound infection $(\mathrm{n}=38,55 \%)$ was the most frequent NI.

A total of 107 bacterial isolates were obtained. The most predominant bacterial isolate was $A$. baumanni 36 (33.6\%), followed by P. aeruginosa 27 (25.2\%), Enterococcus spp 14 (13\%), Staphylococcus aureus 10 (9.3\%) and Escherichia coli 5 (4.6\%). P. aeruginosa was the most encountered microorganism $(22.36 \%)$ in wound cultures, whereas A. baumanni was the most predominant causative agent in blood cultures (14, $32.5 \%$ ) (Figure). 


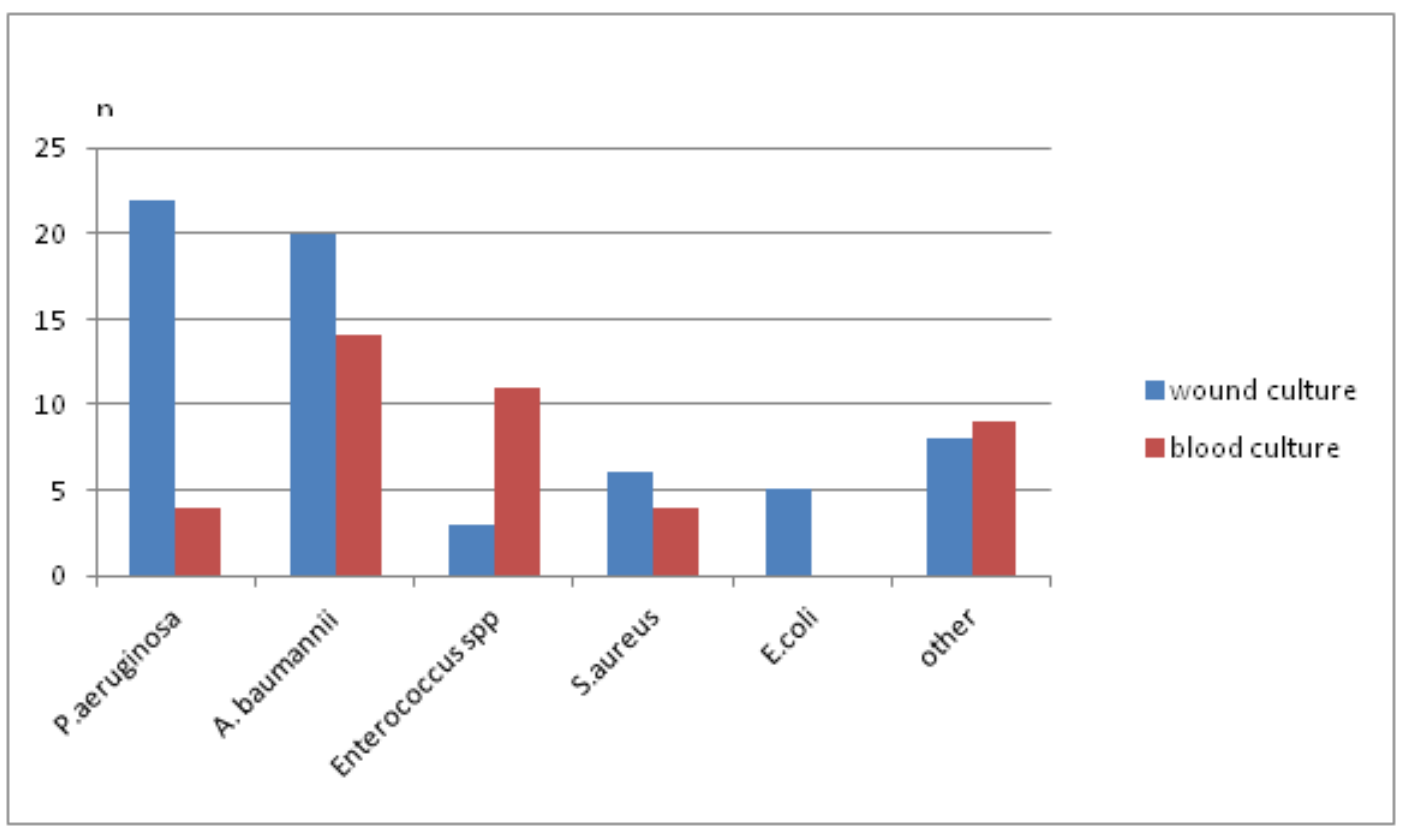

Figure: Organisms isolated from wound and blood cultures

Of 27 P. aeruginosa isolates, 19 (70.3\%), and 29 of 33 A. baumannii isolates $(87.8 \%)$ were multidrug resistant. Of Acinetobacter isolates, 15 had XDR, in Pseudomonas isolates 19 had XDR, whereas none had PDR. Use of invasive device, lenght of stay, ICU lenght of stay and \% TBSA were statistically significant for MDR $A$. baumannii and $P$. aeruginosa $(\mathrm{p}<0.001)$. However, type of injury and comorbidity factors were found statistically insignificant $(p>0.05)$. In logistic regression, length of stay and the invasive device usage were found as risk factors for MDR A. baumannii and P. aeruginosa (Table)

Table: The characteristics and risk factors for multidrug-resistant $A$. baumannii and P. aeruginosa infections.

\begin{tabular}{|c|c|c|c|c|c|c|}
\hline \multirow[b]{2}{*}{ Variable } & \multirow{2}{*}{$\begin{array}{l}\text { MDR (-) } \\
\mathrm{n}(\%)\end{array}$} & \multirow{2}{*}{$\begin{array}{l}\text { MDR (+) } \\
\mathrm{n}(\%)\end{array}$} & \multirow{2}{*}{$\begin{array}{l}\text { Univariate analysis } \\
\mathrm{P}\end{array}$} & \multicolumn{3}{|c|}{ Logistic regression } \\
\hline & & & & Odds Ratio & $95 \% \mathrm{Cl}$ & $\mathrm{P}$ \\
\hline Invasive devices usage & $108(81.2)$ & $25(18.8)$ & $<0.001$ & 4.60 & $1.54-13.73$ & 0.006 \\
\hline $\begin{array}{l}\text { Current antibiotics } \\
\text { usage }\end{array}$ & $311(92)$ & $27(8)$ & $>0,05$ & 0.72 & $0.18-2.80$ & 0.64 \\
\hline & $\begin{array}{l}\text { Median (Min- } \\
\text { Max) }\end{array}$ & $\begin{array}{l}\text { Median (Min- } \\
\text { Max) }\end{array}$ & & & & \\
\hline $\begin{array}{l}\text { Lenght of stay in } \\
\text { hospital }\end{array}$ & $10(2-139)$ & $33(10-144)$ & $<0.001$ & 1.04 & $1.02-1.07$ & $<0.001$ \\
\hline ICU lenght of stay & $0(0-32)$ & $2(0-29)$ & $<0.001$ & 0.99 & $0.93-1.06$ & 0.90 \\
\hline$\%$ TBSA & $12(0-95)$ & $30(9-80)$ & $<0.001$ & 1.02 & $0.99-1.04$ & 0.11 \\
\hline
\end{tabular}

TBSA: Total Body Surface Area, ICU: Intensive care unit, MDR: Multidrug-resistant

Current antibiotics: e.g. first spectrum cephalosporins and ampicillin-sulbactam, invasive devices used:ventilator, central line, and urinary catheter 


\section{DISCUSSION}

There have been standart precautions on practice when caring for all patients with burn injury. The open burn wound is a ready port and increases the environmental contamination present around the patient. This makes major difference in burn versus non- burn patients. The larger the burn size the more vulnerable it is to contamination ${ }^{8}$. The emergence of MDR Gram-negative organisms causing nosocomial infections is a growing problem for clinicians. Inappropriate use of empiric antibiotic therapy can lead to the development of MDR bacteria ${ }^{9}$.

Altoparlak et al found that, the nature of microbial wound colonization, flora changes, and antimicrobial sensitivity profiles should be taken into consideration in using empirical antimicrobial therapy of burned patients ${ }^{10}$.

Considering emerging infection rates as success criteria, our incidence of NI was $12.9 \%$ and incidence density was $9.9 / 1000$ patient days. These rates were lower than other Turkish studies. Alp et al reported an incidence of NI as $11 \%$ and incidence density as $14.7 / 1000$ patient days in a study reviewing 1190 patients in 10 years period ${ }^{11}$. Oncul et al revealed NI rate of 18.2 per 1000 patient days in 169 patients ${ }^{12}$. However, despite the strict rules by infection control committee in our hospital, we were unable to lower the rates as we targeted.

We found the length of stay and the invasive device usage as risk factors for MDR $A$. baumannii and $P$. aeruginosa. Tekin $\mathrm{R}$ et al revealed in 30 patients infected with MDR $A$. baumannii that, high Acute Physiology and Chronic Health Evaluation (APACHE II) score, first excision time of wound, invasive device usage, admission day to hospital, and prior broadspectrum antibiotics usage as the risk factors for NIs ${ }^{13}$. In a study for imipenem-resistant $P$. aeruginosa in burn unit, Ozkurt et al. revealed longer hospitalization time, previous imipenem/meropenem use, previous broad-spectra antibiotic use, as risk factors in the burn unit ${ }^{14}$.

Jung et al. found risk factors MDR A. baumannii bacteremia as infection and respiratory failure at the time of ICU admission, maintenance of endotracheal tube, recent central venous catheter insertion, bacteremia caused by other microorganism after colonization by MDR $A$. baumannii, and prior antimicrobial therapy. And they concluded that minimizing invasive procedures and early removal of the invasive devices should be considered to prevent development of MDR A. baumannii bacteremia ${ }^{15}$.
Wong et al revealed that independent risk factors for the acquisition of MDR A. baumannii, were the APACHE II score on admission and the number of intravascular lines placed ${ }^{16}$.

Increasing antibiotic resistance patterns of the most prevalent isolates recovered during extended hospitalization, impact of \% TBSA and other clinical parameters may affect empirical antimicrobial therapy and patient management decisions during treatment ${ }^{2}$.

In conclusion, due to higher rates of infections by microorganisms capable of developing multidrug resistance like A. baumannii and P.aeruginosa, we believe that strict rules to control infections, lower hospitalization period and the invasive device usage are essential to keep MDR and NI rates lowered or at least in a stable phase.

\section{REFERENCES}

1. Branski LK, Al-Mousawi A, Rivero H, Jeschke MG, Sanford AP, Herndon DN. Emerging infections in burns. Surg Infect. 2009; 10:389-97.

2. Keen EF, Robinson BJ, Hospenthal DR, et al. Incidence and bacteriology of burn infections at a military burn center. Burns 2010; 36:461-8.

3. Horan TC, Andrus M, Dudeck MA. CDC/NHSN surveillance definition of health care-associated infection and criteria for specific types of infections in the acute care setting. Am J Infect Control 2008; 36:309-32.

4. American College of Surgeons. Advanced trauma life support.6th ed. Chicago: American College of Surgeons; 1997.

5. Lund CC, Browder NC. The estimation of areas of burns. Surg Gynecol Obstet 1944; 79:352-8.

6. Clinical and Laboratory Standards Institute. Performance standards for antimicrobial disc susceptibility tests. CLSI Document M100-S12, 2002. CLSI, Wayne, PA.

7. Magiorakos AP, Srinivasan A, Carey RB, et al. Multidrug-resistant, extensively drug-resistant and pandrug-resistant bacteria: an international expert proposal for interim standard definitions for acquired resistance. Clin Microbiol Infect 2012; 18:268-81.

8. Rafla K, Tredget E.E. Infection control in the burn unit. Burns 2011; 37:5-15.

9. Hand WL. Current challenges in antibiotic resistance. Adolescent Med. 2000; 11:427-38. 
10. Altoparlak Ü, Erol S, Akçay MN, Çelebi F, Kadanal1 A. The time-related changes of antimicrobial resistance patterns and predominant bacterial profiles of burn wounds and body flora of burned patients. Burns 2004; 30: 660-4

11. Alp E, Coruh A, Gunay GK, Yontar Y, Doganay M. Risk factors for nosocomial infection and mortality in burn patients: 10 years of experience at a university hospital. J Burn Care Res 2012; 33:37985.

12. Oncül O, Ulkur E, Acar A, et al. Prospective analysis of nosocomial infections in a burn care unit, Turkey. Indian J Med Res 2009; 130:758-64.

13. Tekin R, Dal T, Bozkurt F, et al. Risk Factors for Nosocomial Burn Wound Infection Caused by Multidrug Resistant Acinetobacter baumannii. J Burn Care Res 2013; 24:73-80.

14. Özkurt Z, Ertek M, Erol S, Altoparlak U, Akcay MN. The risk factors for acquisition of imipenem-resistant Pseudomonas aeruginosa in the burn unit. Burns 2005; 31:871-3

15. Jung JY, Park MS, Kim SE, et al. Risk factors for multi-drug resistant Acinetobacter baumannii bacteremia in patients with colonization in the intensive care unit. BMC Infect Dis. 2010;10:228. doi: 10.1186/1471-2334-10-228.

16. Wong TH, Tan BH, Ling ML, Song C. Source. Multi-resistant Acinetobacter baumannii on a burns unit clinical risk factors and prognosis. Burns; 2002 Jun;28(4):349-57. 